\title{
Needed: optics light in Africa
}

\section{Akanihu Kingsley}

Akanihu Kingsley, "Needed: optics light in Africa," Proc. SPIE 9664, Ninth International Topical Meeting on Education and Training in Optics and Photonics, 966420 (24 October 2005); doi: 10.1117/12.2207527 
Ref ETOP : ETOP002

\title{
Needed: Optics light in Africa
}

\author{
Akanihu kingsley
}

\begin{abstract}
Though Africa is known and in many quarters still referred to as the dark continent, should she still be in that state in this day and time in which we live? Data now travels at the speed of light and information reaches every nook and cranny of the earth, and I ask, can some of this not be directed towards Africa? More attention needs to be focused on educating Africa in the fields of photonics and optics to illuminate her because if mother earth has got to progress, no part of her or her children can and should be left behind.
\end{abstract}

\section{Keywords}

That Africa may become more enlightened and aware of the ever increasing and developing array of challenges and opportunities in the fields of photonics and optics.

\section{Summary}

If the truth most be told then it would suffice me to say that in the last 60 years, the growth and rate of development of this field of science has been unprecedented. From the development of High Speed Optical Tracking in 1956 to Theodore Maimans' demonstration of the LASER in 1960. By 1988 we had the Transatlantic Fibre optic cable installed and as recent as 2004, the Photocurable Nanoimprint Lithography (P-NIL). If not already the case, then in the near future, development and innovations in photonics and optics would have a profound impact on the lives and lifestyles of almost every one on this planet. Sadly though, in this emerging field of so much opportunities, Africa is still groping in the dark. As a matter of fact, more than $95 \%$ of Africans living in Africa do not know that there is a field of science known as photonics. The best of optics they know borders around the refraction and reflection of light within two media - discoveries made in the 19th century.

This, my friends, is the present day knowledge status of Africa as regards photonics and optics.

I believe it is time the whole world began to take some thoughts towards educating Africa in this field of boundless opportunities known as optics and photonics. I believe that Africa should be given more focus and attention when it comes to the education and training in optics and photonics. She cannot forever be dependent on the West for every of her technology and resource. No. There is need for the optics and photonics world to give a little, not to much, just a little more to Africa. And that little will spread like a tropical wild fire all across the continent.

Africa really does not need more financial loans and grants or debt relief's. The kind of loans and grants She needs are educational. That is real development and that is what Africa craves for. A wise men once said that one rich man in the midst of six poor men equals seven poor men. Educationally speaking, that's the predicament the world is faced with today. If you take the time to find out, you will discover that the percentage of Africans, actively or passively, engaged in this field is so little and very near inconsequential. When I speak of Africans here, I speak of native Africans living in 
Africa. This is not because they do not want to be involved. On the contrary, I personally know over 100 people who would be willing to pay through their noses to receive an education in this field. The reasons are, in my own point of view, two pronged.

The first reason addresses the ignorant. Many do not even know that such a field exist. Africa is presently the fastest growing wireless communications end users in the world, and they do not even know that there is a relationship between wireless communication and optics and photonics. Today, the fastest growing mobile communications network in the world, Globacom, is in Nigeria, my home country, and it may amaze you to know that almost everyone is linked up to this fibre optic network without even knowing the discipline from which this kind of network stems. That is the level of ignorance we are faced with in Africa and I believe optics and photonic societies all over the world can do the least by enlightening Africa of this relatively new discipline.

The second reason is the dearth of opportunities for those who are not in the ignorant bracket. Young and willing minds are scattered all over the continent eager to follow a career path in optics and photonics. But unfortunately, most are discouraged largely because there are next to no institutions where they can study optics and photonics at a post high school level. I can authoritatively say so because, a few years ago, after knowing about and personally carrying out our findings on the discipline, I and a few friends craved to study optics and photonics. Regrettably, we could not find one post high school institution where we could bring our dreams to reality. I made a couple of attempts at foreign institutions, but the embassies never believed I could pay for the tuition as an international student. This led to the finding of The SOCIETY FOR THE PROMOTION OF PHOTONICS AND OPTICS TECHNOLOGY IN AFRICA (SPOTAFRIK). If the applications and innovations of this field of study is growing, then her number of students and study should do the same geometrically, especially in Africa. In a sentence, that is the objective of SPOTAFRIK.

Having highlighted these myriad of problems that plague the study of optics and photonics in the continent, it would only be fair to suggest workable solutions that adequately address these problems.

My first suggestion would be to tackle the problem of awareness. We can work out a way to systematically bring an awareness of this discipline, its contribution and benefits to Africa and Africans. A good start would be by organizing a couple of this type of seminars and conferences in major cities across Africa.

In Africa, if you go to a high school and ask a student what he would like to study after leaving high school, he most likely would mention disciplines that he is familiar with. So I suggest we catch them young by holding regular and periodic seminars in high schools all across the continent, letting them know the benefits of studying optics and photonics at a higher level. In Nigeria, for instance, working in a telecommunications industry is considered a well paying job. So partnering with telecommunications companies like Globacom, SPOTAFRIK is presently working out plans to hold such seminars in select schools around the country, enlightening the students, and letting them know that their expertise would be in high demand from companies like Globacom and other telecommunications giants around the world would should they take up studies in optics and photonics. This may sound like a carrot and stick approach, however SPOTAFRIK is open to other suggestions

Secondly, I strongly believe that opportunities should be brought into Africa. As long as these opportunities remain outside of Africa, they are no more than dreams to those who seek them. The greatest challenge an African student who wants to study abroad faces 
is the outrageous fees he has to pay as an international student. Unless such issues are addressed by home institutions, for many Africans, studying abroad will not even be an option. On the other hand, the reason why most African institutions do not offer courses in optics and photonics are because they have no trained tutors for them. And even if they did, bureaucratic bottlenecks would hamper their accreditations as most colleges and universities are state owned.

Therefore, I suggest that specialized institutes and monotechnics be started around Africa solely for the teaching of optics and photonics. For tutors, working closely with organizations like this and SPIE, modalities could be worked out whereby sabbatical leaves could be spent by their members and volunteer lecturers at such institutes for the first few years or until such institutes produce graduates that could be retained as lecturers in the institutes.

These suggestions are not exhaustive and is open to constructive criticism with the aim of producing better alternatives. Though constrained, organizations like SPOTAFRIK are working towards directing some optics light towards Africa. All we are asking is for the rest of the world to join us in making sure that Africa sees the light in optics and photonics. 